\title{
MOŻLIWOŚCI KSZTAŁTOWANIA PRZYLEGAJĄCYCH STRUKTUR SZKLARNIOWYCH I ICH WPEYW NA GOSPODARKĘ ENERGETYCZNĄ BUDYNKU
}

\begin{abstract}
Sposób kształtowania struktur szklarniowych w układzie przylegającym reprezentuje koncepcję przegrody energetycznej, wdrażającej wszelkie rozwiązania innowacyjne uwzględniające pasywny system samoregulacji ciepła, ochrony przeciwsłonecznej, naturalnej wymiany powietrza w zależności od stopnia nasłonecznienia a zarazem zorientowania wobec kierunków stron świata. Warunki te determinują charakter przestrzeni szklarniowej dodanej do budynku po stronie nasłonecznionej, scharakteryzowanej, jako pasywny kolektor ciepła lub po stronie o ograniczonej insolacji, jako bufor termiczny. Dodana struktura szklarniowa poddana insolacji warunkuje zyski cieplne z promieniowania słonecznego zimą zmagazynowane $\mathrm{w}$ elementach konstrukcyjnych a zamknięta przestrzeń międzypowłokowa pełni rolę bufora cieplnego w tym okresie. Latem poddana jest strategii chłodzenia, polegającej na pozbyciu się nadmiaru ciepła $\mathrm{z}$ obiektu wskutek właściwej dystrybucji powietrza wentylowanego i ochronie przeciwsłonecznej. Wydzielona przestrzeń szklarniowa, tworząca obrzeżną strefę budynku przyczynia się do ograniczenia zapotrzebowania na energię i pełni rolę modyfikatora mikroklimatu wnętrza. Przedstawione zostały przylegające struktury szklarniowe w układzie pionowym szklenia oraz arkady słonecznej, na długości nasłonecznionej elewacji, które najpełniej dostosowane są do wykorzystania energii z promieniowania słonecznego. Przykłady zrealizowanych obiektów o określonych wyżej uformowaniach struktur szklarniowych stały się bazą analiz energetycznych w formie schematów, obrazujących zależności między strukturą budynku a gospodarowaniem energią w systemach pasywnego jej pozyskiwania. Artykuł podkreśla korzyści energetyczne płynące $\mathrm{z}$ zastosowania dodanych struktur przeszklonych do budyn$\mathrm{ku}$ wynikające $\mathrm{z}$ jego uformowania w warunkach klimatu umiarkowanego.
\end{abstract}

Słowa kluczowe: przegroda energetyczna, efekt szklarniowy, zysk energetyczny, przestrzeń buforowa, pasywny system

\footnotetext{
${ }^{1}$ Joanna Biedrońska, Politechnika Śląska, Katedra Teorii, Projektowania i Historii Architektury, ul. Akademicka 7, 44-100 Gliwice, tel.32/2371685, e-mail: joanna.biedronska@polsl.pl
} 


\section{Wstęp}

Prototypem współczesnych struktur przeszklonych były ogrody zimowe XIX i XX wieku wykorzystujące efekt szklarniowy do rozważań na temat zjawisk zachodzących we wnętrzu, przy udziale słońca i wiatru, w celu zapewnienia roślinom i użytkownikom właściwego mikroklimatu. Wszelkie niedogodności natury użytkowej pojawiające się w szklarniach w wyniku przegrzania czy niedostatecznej wymiany powietrza miały podkreślić silne związki pomiędzy kształtowaniem struktur szklarniowych a komfortem użytkowania przeszklonego wnętrza. Jeszcze do niedawna szklarnie o światowej renomie i historycznym znaczeniu pochłaniały ogromne ilości paliw naturalnych w celu utrzymania odpowiednich warunków bioklimatycznych we wnętrzach w okresie np. zimy. W obecnych czasach zmuszających nas do energooszczędności, do poszanowania środowiska, konieczne stały się rozwiązania wykorzystujące energię słoneczną, jako źródło energii odnawialnej, gdy bierny sposób pozyskiwania energii ze słońca okazał się godny uwzględnienia. Współczesna wiedza na temat kształtowania architektury bioklimatycznej i - w węższym ujęciu - architektury słonecznej, opartej na gruntownej analizie relacji budynku z otoczeniem, a także zaawansowane rozwiązania $\mathrm{w}$ zakresie instalacji i technologii materiałowej dają większe możliwości wznoszenia struktur szklarniowych mających cechy budownictwa zrównoważonego w pełnym tego słowa znaczeniu. Wobec pogłębianej wiedzy, doświadczeń w dziedzinie techniki wytwarzania i rozwoju technologii nadającej przegrodzie szklanej specyficzne właściwości, stworzona została możliwość kontynuacji idei szklanych struktur architektonicznych XX wieku. Realizowane są śmiałe projekty, których celem jest wytyczenie nowych dróg w architekturze, autorstwa światowej sławy architektów: The Great Glasshouse w Walii projektu Normana Fostera, Glasshaus RHS Garden w Wisley projektu architekta Petera van der Toorn Vrijthoff czy też w bardziej odległym miejscu i klimacie Gardens by the Bay w Singapurze wg projektu Wilkinson Eyre Architects. Te spektakularne, wielkoskalowe obiekty architektury bioklimatycznej nazwane zostały ogrodami aktywnymi energetycznie. Sprzyja im rozgłos, nagrody, ale też dowodzą, jakim wartościom podporządkowana zostaje współczesna architektura niezależnie od skali i przeznaczenia budynków zawierających w swej strukturze czy w swym obrysie przeszklone struktury.

\section{Pasywny sposób pozyskiwania energii w odniesieniu do struk- tur szklarniowych}

Rozwój technologii oraz wieloletnie doświadczenia w zakresie budowania szklanych struktur, skłoniły architektów do bliższego przyjrzenia się, jaki wpływ posiada ukształtowanie zewnętrznej powłoki szklanej na gospodarkę energetyczną budynku. Zależność ta wpływa na wydajność energetyczną i formę, które determinują charakter architektury, świadczący o niskim zapotrzebo- 
waniu na energię. Obudowa zewnętrzna budynku nie może opierać się tylko na walorach estetycznych jej uformowania, ale przede wszystkim musi odpowiadać parametrom przestrzenno - technicznym zapewniającym zastosowanie zasad racjonalnej gospodarki energetycznej. Powinna być przegrodą reagującą na zmienne warunki otoczenia, w kontrolowany sposób wykorzystująca jego energię, pozwalającą na tworzenie kompleksowych systemów regulacji mikroklimatu wewnątrz budynku. W najprostszy sposób należy wykorzystać zjawiska fizyczne towarzyszące biernemu sposobowi pozyskiwania energii ze słońca i wiatru bez uciekania się do konieczności używania urządzeń zasilanych energią zewnętrzną. Strategie pasywne bazują na rozwiązaniach zmniejszających zapotrzebowanie budynku na energię grzewczą wykorzystując do tego celu słońce w porze zimowej oraz do chłodzenia budynku w porze letniej, gdy wykorzystywany jest ruch powietrza w sposób niewymuszony mechanicznie a odpowiednią ochronę przed przegrzewaniem stanowią regulowane osłony przeciwsłoneczne np. systemy żaluzjowe. W przypadku stosowania rozwiązań pasywnych szczególnie istotny jest dobór odpowiednich materiałów i rozwiązań architektoniczno-budowlanych pozwalających wykorzystać strukturę budynku do pochłaniania, magazynowania oraz rozprowadzania pozyskanej energii promieniowania słonecznego [2]. Przykładem są ściany i stropy, stanowiące konstrukcję budynku, które mogą pełnić funkcję magazynu ciepła a w konfiguracji ze szklaną strukturą tworzą rodzaj pasywnego kolektora ciepła. Aby uzyskać jak największe zyski energetyczne zimą konieczne staje się ukierunkowanie struktur przeszklonych na południe [1].

\section{Struktury szklarniowe w układzie przylegającym}

Rolę kolektora ciepła najlepiej spełniają szklarnie, które pozostają w konfiguracji przylegającej do budynku, a więc tworzą jego strefę obrzeżną, występując w postaci ogrodów zimowych, przeszklonych pasaży, arkad zewnętrznych, itp. Taka relacja przestrzenna względem budynku sprzyja wyeksponowaniu szklarni na oddziaływanie promieni słonecznych, a zatem wzrasta możliwość wykorzystania energii słonecznej w jej przestrzeni [5]. Najefektywniejszemu wykorzystaniu energii słonecznej i światła dziennego służy wydłużenie bryły budynku na osi wschód-zachód i uzyskanie w ten sposób linearnej elewacji południowej. Ten rodzaj kształtowania struktury budynku reprezentuje przeszklona fasada dwupowłokowa o szerokiej przestrzeni pasmowej.

\subsection{Struktura szklarniowa w układzie pionowym szklenia - poddana insolacji}

W układzie pionowym szklenia dodana struktura stanowi typowy, szeroko już dzisiaj stosowany w wysokich budynkach biurowych, przykład podwójnej fasady, wentylowanej pomiędzy dwiema warstwami obudowy na całej wysokości budynku. 
A.

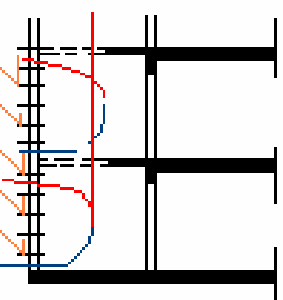

B.

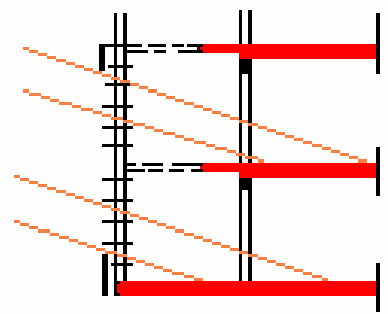

Rys. 1. Schematy: A - wentylacji naturalnej i ochrony przeciwsłonecznej latem, B -wykorzystania energii promieniowania słonecznego do akumulacji ciepła w elementach konstrukcyjnych zimą

Fig. 1. Charts: A - natural ventilation and sun protection in summer; B - the utilization of sun radiation for accumulation of energy in building construction elements during winter

A.

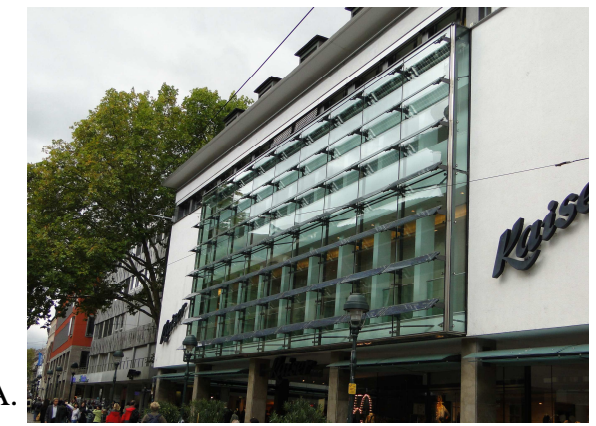

B

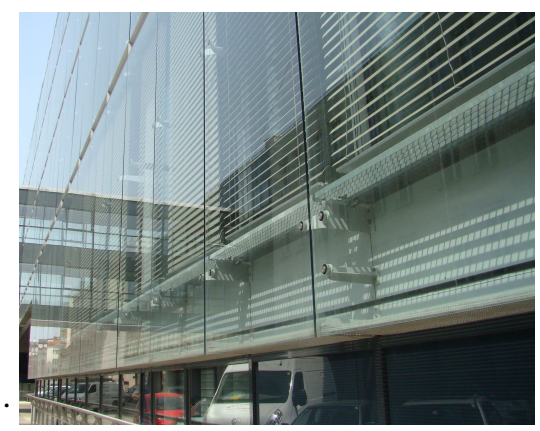

Rys. 2. Budynek o układzie dostawionej, pionowej strukturze szklanej: A - system żaluzji umieszczony na zewnątrz przeszklonej struktury, Freiburg; B - system żaluzji w przestrzeni międzypowłokowej, Wiedeń. Fot.: J. Biedrońska

Fig. 2. Building with adjacent, vertical glass structure: A - system of blindes placed outside of the glass structure, Freiburg; B - system of blinds placed within the glass structure, Vienna. Photo: J. Biedrońska

W przegrodach spełniających wymogi energetyczne musi następować infiltracja zapewniająca optymalną wymianę powietrza we wnętrzach w sposób pozwalający na ograniczenie strat ciepła i utrzymanie należytych parametrów mikroklimatu w pomieszczeniach. Dodana struktura szklarniowa poddana insolacji warunkuje zyski cieplne z promieniowania słonecznego zimą zmagazynowane w elementach konstrukcyjnych a zamknięta przestrzeń międzypowłokowa pełni rolę bufora cieplnego w tym okresie. Systemy kształtowania przestrzeni międzypowłokowej, ich położenie, wielkość i rodzaj otworów dostosowanych do przepływu powietrza mają różny wymiar w specyfikacji budynków o podwójnej fasadzie. Ich koncepcje polegają na zastosowaniu dwóch zewnętrznych szklanych powłok odsuniętych od siebie w odległości od $25 \mathrm{~cm}$ do $90 \mathrm{~cm}$ i większej mogących stanowić przestrzeń użytkową, np drogę ewakuacyjną czy strefę rekreacyjną. 


\subsection{Struktura szklarniowa $w$ formie arkady słonecznej}

Szczególnym przypadkiem rozwiązania przestrzeni dwupowłokowej jest arkada słoneczna, której fasada pochylona jest pod kątem. Uważa się, że inspiracją do zaprojektowania arkady stała się dziewiętnastowieczna architektura ogrodowa. Zastosowana zasada ukształtowania południowej elewacji w formie słonecznej arkady w budynkach administracyjnych Fabryki Ogniw Słonecznych w Gelsenkirchen oraz podobna w swych założeniach projektowych Solar Fabrik we Freiburgu była przytaczaną często literaturowo realizacją w latach 90-tych XX wieku. Szklany system osłonowy nachylony pod kątem 73 stopni dostosowany jest do kierunku padania promieni słonecznych zimą. W okresie tym arkada pełni rolę bufora termicznego stanowiąc skuteczną ochronę przed przemarzaniem w okresie grzewczym i jednocześnie rolę kolektora ciepła, gdy efekt szklarniowy umożliwia pasywne zyski ciepła magazynowane w żelbetowych elementach konstrukcyjnych. W lecie zaś w systemie pasywnym istotną rolę odgrywa ochrona przeciwsłoneczna wykorzystująca elementy skutecznie chroniące przed przegrzaniem oraz przewietrzanie termicznie oddzielonej od budynku przestrzeni przeszklonej. Naturalna wentylacja odbywa się na zasadzie konwekcji uzyskanego z nasłonecznienia ciepła a następnie za pośrednictwem otworów i kanałów cyrkulacyjnych przekazana do wnętrza i wyprowadzona na zewnątrz. Zasysane przez dolne otwory chłodne powietrze dostaje się do środka a następnie ogrzane przez słońce powietrze unosi się do góry i wyprowadzone zostaje na zewnątrz górnymi otworami. Następuje wymiana powietrza oraz naturalny ruch jego mas ku górze bez zewnętrznych urządzeń wymuszających. Dodatkowo innowacyjność obu koncepcji polega na zintegrowaniu pasywnych sposobów wykorzystania energii słonecznej z wprowadzeniem aktywnych systemów w tym wypadku elementów fotowoltaicznych wykorzystujących słońce do produkcji energii elektrycznej na potrzeby obiektu [4].

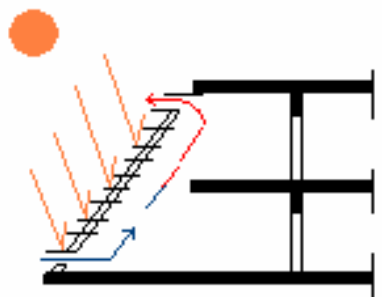

A.

Rys. 3. Schematy: A- wentylacji naturalnej i ochrony przeciwsłonecznej latem, B -wykorzystania energii promieniowania słonecznego do akumulacji ciepła w elementach konstrukcyjnych zimą.

Fig. 3. Charts: A - natural ventilation and sun protection in summer; B - the utilization of sun radiation for accumulation of energy in construction elements during winter 
Przykładem strategii pasywnego wykorzystania energii w budownictwie jednorodzinnym przy wykorzystaniu pochyłej struktury szklanej jest osiedle szeregowej zabudowy w Riedholz w Szwajcarii (2011) projektu Aarplan Architekten AG (Rys. 4, 5).
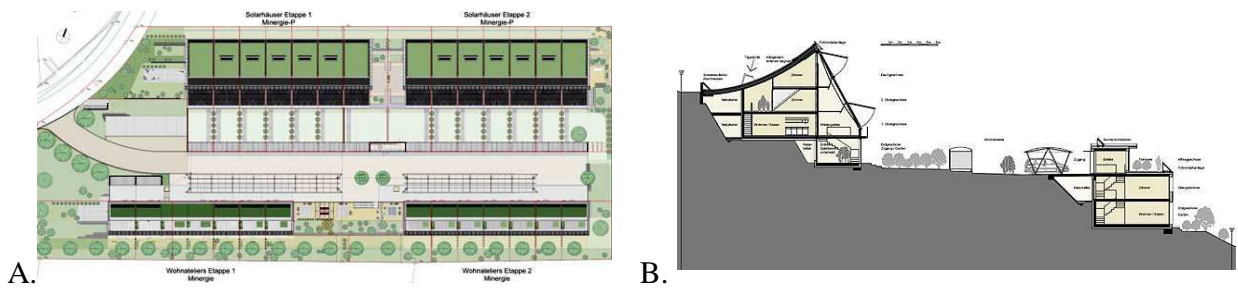

Rys. 4. Osiedle słoneczne Riedholz, Szwajcaria, Aarplan Architekten AG, A - Rzut zabudowy szeregowej; B - Przekrój Osiedla słonecznego źródło:

http://www.aarplan.ch/gebaut/siedlungsbau/solarsiedlung-riedholz/ dostęp 26.03.2014

Fig. 4.The Sunny Estate Riedholz, Switzerland, Aarplan Architekten AG, A - plan of buildings; B -Section of Sunny Estate buildings. Source:

http://www.aarplan.ch/gebaut/siedlungsbau/solarsiedlung-riedholz/ dostęp 26.03.2014

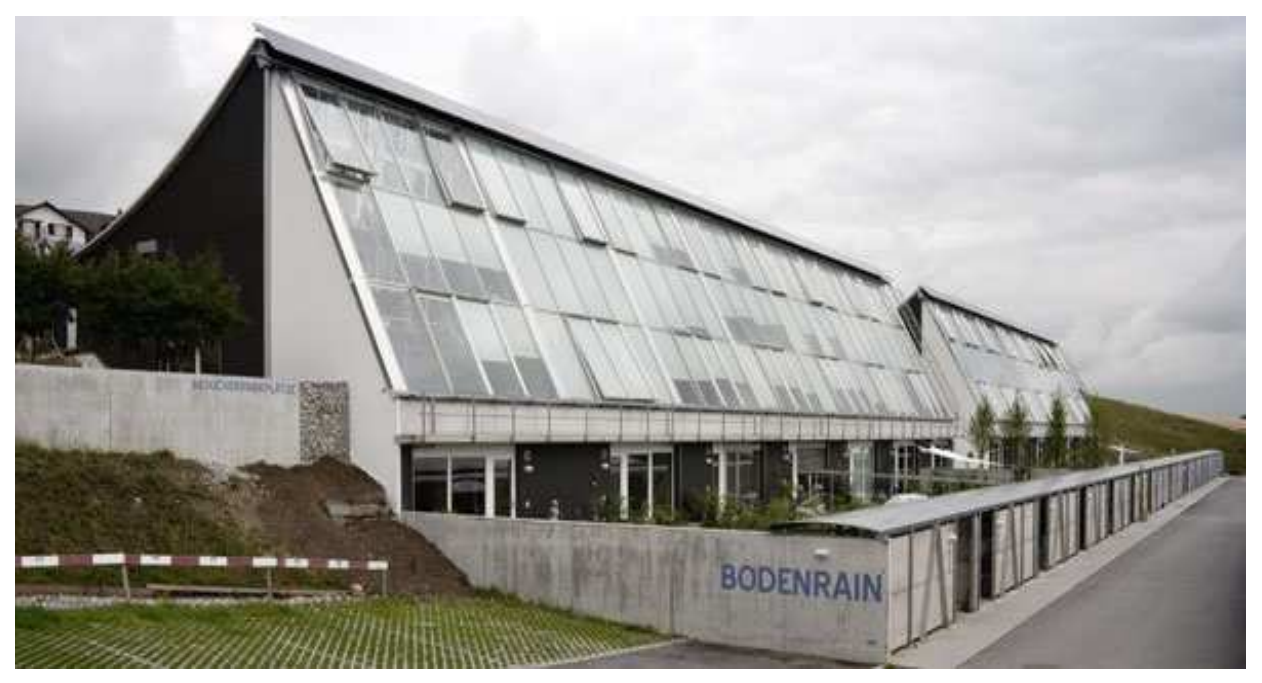

Rys.5. Widok budynków Osiedla Słonecznego Riedholz

Fig.5. View of Sunny Estate buildings Riedholz. Source:

http://www.aarplan.ch/gebaut/siedlungsbau/solarsiedlung-riedholz/ dostęp 26.03.2014 


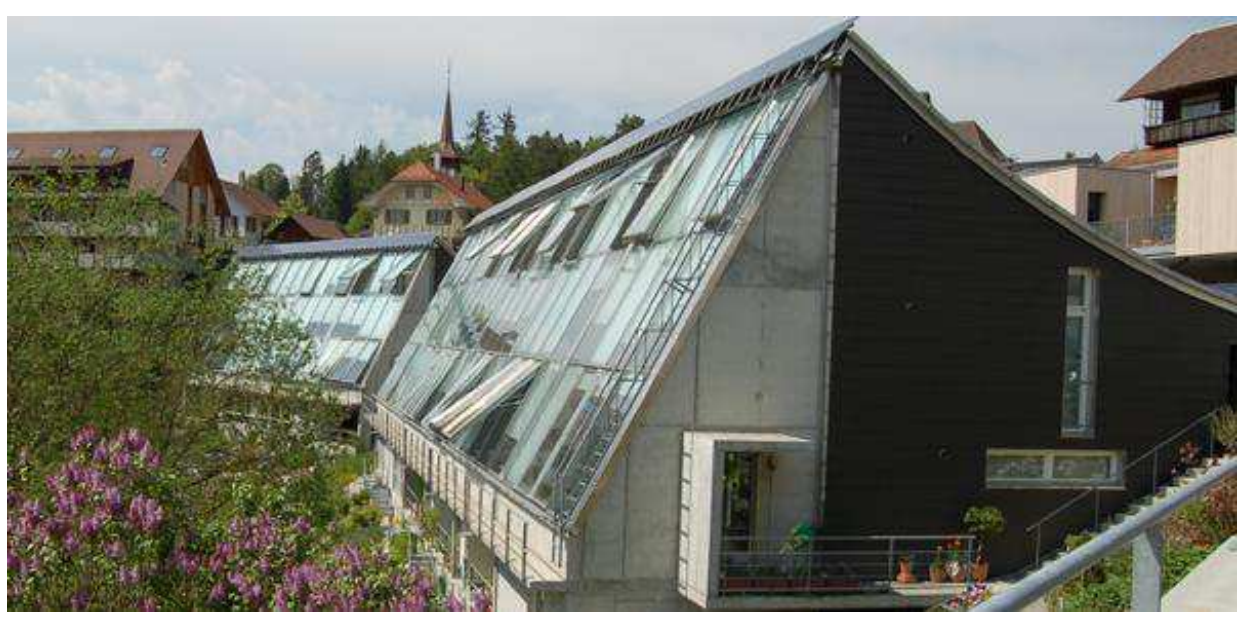

Rys. 6. Widok budynków Osiedla Słonecznego Niederscherli

Fig. 6. View of Sunny Estate buildings Niederscherli. Source: http://www.aarplan.ch/gebaut/siedlungsbau/ dostęp 26.03.2014,

Powstałe „słoneczne osiedla” w Zallikofen (1995), Niederscherli (2004), Innerberg (2006) przedstawiają tę samą zasadę kształtowania przeszklonej arkady, co we Freiburgu i Gelsenkirchen, reprezentują mniejszą skalę i są kontynuacją architektonicznej myśli gospodarowania energią odnawialną w budynku. System ogrzewania wykorzystuje bierny sposób pozyskiwania energii cieplnej ze słońca. Nachylona pod kątem 60 stopni przeszklona fasada ogrodu zimowego skierowana jest na południe. Betonowe ściany i stropy stanowiące strukturę budynku pełnią rolę magazynów ciepła zakumulowanego w ciągu zimowego dnia. W gorącej porze roku do chłodzenia budynku wykorzystane jest zimne nocne powietrze zasysane w północnej części budynku i kanałem przesłane do ogrodu zimowego. W ciągu dnia przy silnym natężeniu promieniowania słonecznego, aby uniknąc przegrzania, szyby są osłaniane tekstylnymi roletami a otwory dolne i górne są otwarte by umożliwić naturalną wentylację. Nazwa Słoneczne Osiedle („Solarsiedlung”) wywodzi się z maksymalnego wykorzystania energii słońca zarówno w pasywnym jak i aktywnym systemie. Oprócz południowego ukształtowania strefy przeszklonej arkady pełniącej rolę kolektora ciepła, zastosowano elementy fotowoltaiczne, wykorzystujące energię słońca do produkcji prądu pokrywające zapotrzebowanie w 30\% i kolektory słoneczne do ogrzewania wody [3]. 


\subsection{Struktura szklarniowa w układzie pionowym, przylegającym - o nikłym stopniu insolacji}

Przylegająca struktura szklarniowa znajdująca się po zacienionej stronie budynku, do której nie dochodzi bezpośrednio promieniowanie słoneczne, stanowi bufor termiczny pomiędzy środowiskiem zewnętrznym a mikroklimatem wnętrza, powodując np. ograniczenie strat nagromadzonego ciepła w okresie zimy.

A.

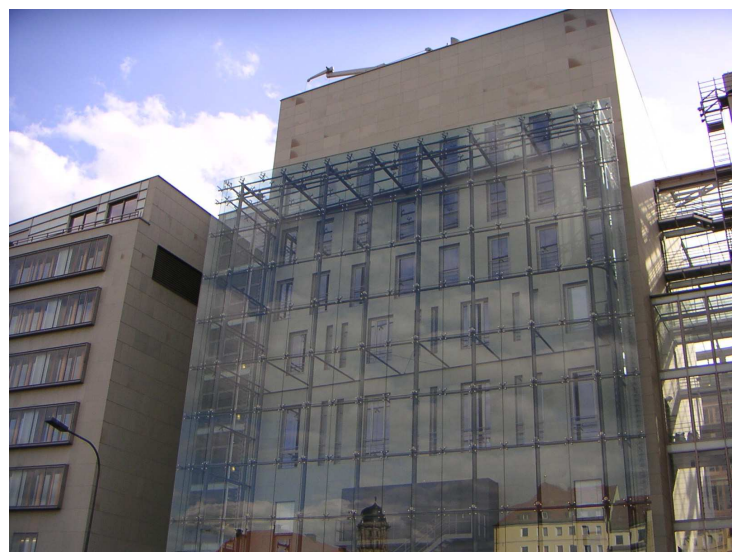

B.

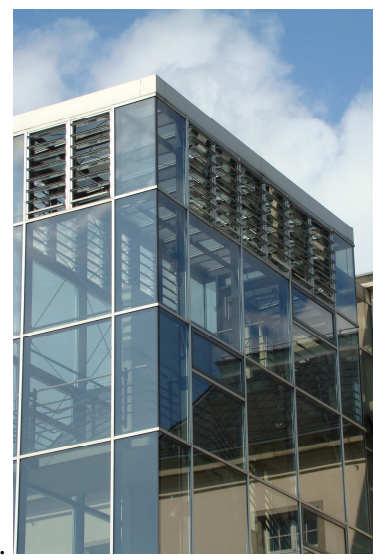

Rys. 7. Struktura szklarniowa pełniąca rolę termobuforową: A - ściana północna budynku, Berlin; B - wertykalna obudowa klatki schodowej, Drezno. Fot.: J. Biedrońska

Fig. 7. Greenhouse structure accomplishing the role of thermal buffer zone: A - the northern wall of the building, Berlin; B - the vertical casing of the staircase, Dresden. Photo: J. Biedrońska

W wyniku lokalizacji szklarni na obrzeżu budynku niezależnie od stron świata powstają przestrzenie termobuforowe, kurtyny cieplne, zmniejszające wymagania izolacyjne wewnętrznych fasad. W warunkach klimatu umiarkowanego zamknięcie przeszklonym buforem powoduje wzrost temperatury o min. $5^{\circ} \mathrm{C}$.

\section{Podsumowanie}

W warunkach klimatycznych Polski powinno się uwzględniać i promować projektowanie budynków pozyskujących ciepło słoneczne w pasywnym sposobie pozyskiwania energii. Istnieje silny związek między kształtowaniem przestrzennym budynku a sposobem pasywnego ogrzewania i chłodzenia. W każdym przypadku należałoby przeanalizować koncepcję dodania struktury szklarniowej, ukierunkowanej na słońce, bowiem jej kształt, wielkość, układ przestrzenny mają korzystny wpływ na bilans cieplny budynku, jego racjonalną gospodarkę energetyczną oraz mikroklimat wnętrza. Struktura szklarniowa 
w układzie przylegającym, stanowiąca całościową przegrodę, wydaje się być najefektywniejsza poprzez wykorzystanie zjawisk fizycznych przypisanych do pasywnego systemu pozyskiwania energii.

\section{Literatura}

[1] Biedrońska J.: Oszklona przestrzeń buforowa w systemie zysków pośrednich, Kierunki rozwoju budownictwa energooszczędnego i wykorzystania odnawialnych źródeł energii na terenie Dolnego Śląska, Oficyna Wydawnicza Politechniki Wrocławskiej, Wrocław 2013

[2] Chwieduk D.: Energetyka słoneczna budynku, Wydawnictwo Arkady, Warszawa 2011.

[3] Hugli A.: Solarsiedlung Riedholz- Maximaler Komfort be minimalem Energieverbrauch, Sonne, 2011, s. 6-7.

[4] Marchwiński J., Zielonko-Jung K.: Współczesna architektura proekologiczna, Wydawnictwo Naukowe PWN, Warszawa 2012.

[5] Marchwiński J. Aspekt użytkowy przestrzeni szklarniowych w budynkach biurowych i przemysłowych Część 2, Świat szkła 3/2005

[6] Zielonko-Jung K., Marchwiński J.: Łączenie zaawansowanych i tradycyjnych technologii w architekturze proekologicznej, Oficyna Wydawnicza Politechniki Warszawskiej, Warszawa 2012

\section{AN OPPORTUNITY FOR SHAPING OF THE ADJACENT GREENHOUSE STRUCTURES AND THEIR INFLUENCE ON ENERGY MANAGMENT OF A BUILDING}

\section{S u m m a r y}

The proposed method of designing and shaping of the greenhouse structures adjacent to a building represents a concept of energy barrier taking advantage of every innovative approach including the passive system of self-regulation of heat, sun protection, and natural air exchange dependent on sun exposure as well as matching the current Earth position. The discussed conditions determined the character of greenhouse space added to the buildings on the sunny side characterized as a passive collector of heat or on the other side with limited insolation as energy barrier. The added greenhouse structure exposed to insolation yields heat gains from sun radiation during the winter and stores the energy in the construction elements while the sealed glazed structures act as thermal barrier. During summer the entire concept is reversed and the heat excess is removed from the building by combination of proper ventilation and sun protection techniques resulting in lowering building temperature. The greenhouse structure, which surrounds a building lowers the demand for energy and acts as modifier of the interior microclimate. The presented adjacent greenhouse structures were introduced with a perpendicular glass arrangement together with the sunny arcade along the space of the sunny elevation, which is the best way for sun radiation energy utilization. The examples of the buildings modified accordingly to the abovepresented scenario became the basis for the heat balance analysis in the form of charts showing the relationship between the greenhouse structures and the passive energy systems. The presented paper stresses energy benefits from the use of the added glass glazed structures under the condition of the moderate climate. 
Keywords: energy barrier, greenhouse effect, energy benefit, buffer space, passive system

Przestano do redakcji: 01.12.2014 $r$.

Przyjęto do druku: 22.06.2015 r.

DOI: $10.7862 / \mathrm{rb} .2015 .31$ 